\title{
Assessment of Arsenic Concentrations and Estimated Daily Intake of Arsenic from Rice (Oryza sativa) in Ron Phibun District, Southern Thailand
}

\author{
Pornpun Phimol, Parichart Visuthismajarn, Chitsan Lin, and Sanae Rukkur
}

\begin{abstract}
Arsenic is a chemical element present in the environmental from both natural and human source. The accumulation of the excessive amounts of arsenic in rice can cause health problems in consumer as rice is a staple food mainly consumed in Thailand. The purpose of this study was to investigate the concentrations of arsenic in local rice grains and to assess the exposure to arsenic through local rice consumption. Rice samples were randomly collected from three sub districts of Ron Phibun district based on the rice cultivation areas. The concentrations of arsenic contaminated in rice sample cultivated in Ron Phibun district, southern Thailand, the abandoned tin mining site, were investigated using inductively coupled plasma optical emission spectrometry (ICP-OES) coupled with microwave-assisted technique under high pressure and temperature conditions. The estimated daily intake, common index for metal transfer from plant to human, was used to assess the health risk from arsenic through local rice consumption. It is found that the arsenic concentrations were in the range of $0.291-1.361 \mathrm{mg} / \mathrm{kg}$ which were lower than Thai FDA recommendation. The estimated daily intake (EDI) of arsenic by the local people ranged from 1.522 to $7.120 \mu \mathrm{g} / \mathrm{day}$ $\mathrm{kg}$ body weight. Although the estimated daily intake values of arsenic through rice consumption were lower than the standard, the potential health risk from exposure to arsenic need more attention.
\end{abstract}

Index Terms-Arsenic, estimated daily intake, heavy metal, rice.

\section{INTRODUCTION}

Thailand is one of the largest rice exporter in the world. Rice is the main food for domestic consumption and is one of the most important economic crop in Thailand. People can be exposed to heavy metal through the rice consumption. Ron Phibun district, Nakhon Si Thammarat province, located in southern Thailand, has a regional history of arsenic contamination. Geologically, Ron Phibun is part of the Southeast Asian Tin Belt [1]. Many research have been carried out on the assessment of potential health risks for inhabitants in the vicinity of hazardous sites through their

Manuscript received December 13, 2016; revised February 23, 2017

Pornpun Phimol is with Faculty of Environmental Management, Prince of Songkla University, Thailand (e-mail: p.phimol@gmail.com).

Parichart Visuthismajarn was with Faculty of Environmental Management, Prince of Songkla University, Thailand (e-mail: parichart.v@psu.ac.th).

Chitsan Lin is with the Deptartment of Marine Environmental Engineering, National Kaohsiung Marine University, Taiwan (e-mail: ctlin@mail.nkmu.edu.tw).

Sanae Rukkur is with Rajamangala University of Technology Srivijaya, Thailand (e-mail: sanae.r@rmutsv.ac.th). exposure to environmental heavy metals via consumption of farm crops [2]-[10]. Skin cancer was first reported in 1987 among other observed symptoms. Several health risk studies have been carried out in Ron Phibun [1], [11], [12]. Arsenic, the toxic heavy metal, has been identified as health risk by World Health Organization [13]. It is a chemical element presents in the environment from both natural and human sources, including erosion of arsenic-containing rocks, volcanic eruptions, contamination from mining and smelting ores, and the use of arsenic compounds as medicines, herbicides and wood preservatives. It is found in water, air, soil and foods [14]. Chronic exposure of arsenic includes dermal lesions, peripheral neuropathy, skin cancer, and peripheral vascular disease. Major dermatological signs are nelano-keratosis, melanosis, spotted and diffuse keratosis, leucomelanosis, and dorsal keratosis [15]. Arsenic is taken up by plants through pathways for nutrients. Compared with other cereals, such as wheat and barley, rice has generally a much higher arsenic concentration due to rice being the only major cereal crop grown under flooded conditions. This leads to both arsenate and arsenite building up in high concentrations close to the root and have evolved efficient mechanisms of capturing them from soil solution [16].

It has been reported that the consumption of local rice grown in the arsenic contaminated soil was one of the major source of arsenic exposure to the population [17]. Several studies have reported the accumulation of arsenic in rice grains cultivated in regions with high levels of arsenic in groundwater [18]-[20].

Dietary intake is the main route of exposure to heavy metals for most people [21]. The information about heavy metal concentrations in food and the dietary intake is very important for risk assessment of human health [22]. The WHO provisional guideline value of arsenic in food is 0.02 $\mathrm{mg} / \mathrm{kg}$ and a Maximum Allowable Daily Body Load (MADL) of total arsenic of $50 \mu \mathrm{g} / \mathrm{kg}$ bw/day was set in 1967 by the WHO. This study was aimed to investigate the concentration of arsenic in rice cultivated in the vicinity of the abandoned Tin mining site and evaluate the estimated exposure of arsenic through rice consumption.

\section{MATERIALS AND METHODS}

\section{A. Study Area}

Ron Phibun District, Nakhon Si Thammarat Province is located in the southern part of Thailand as depicted in Fig. 1. Ron Phibun district was selected for the study area due to the occurrence of arsenic contamination and the adverse effects 
of arsenic exposure to human health. Sample were randomly collected from three sub districts of Ron Phibun district including of Khuan Chum, Khuan Koei and Khuan Phang selected based on the rice cultivation areas. The sampling locations were identified by Global Positioning System (GPS) receiver (see Table I).

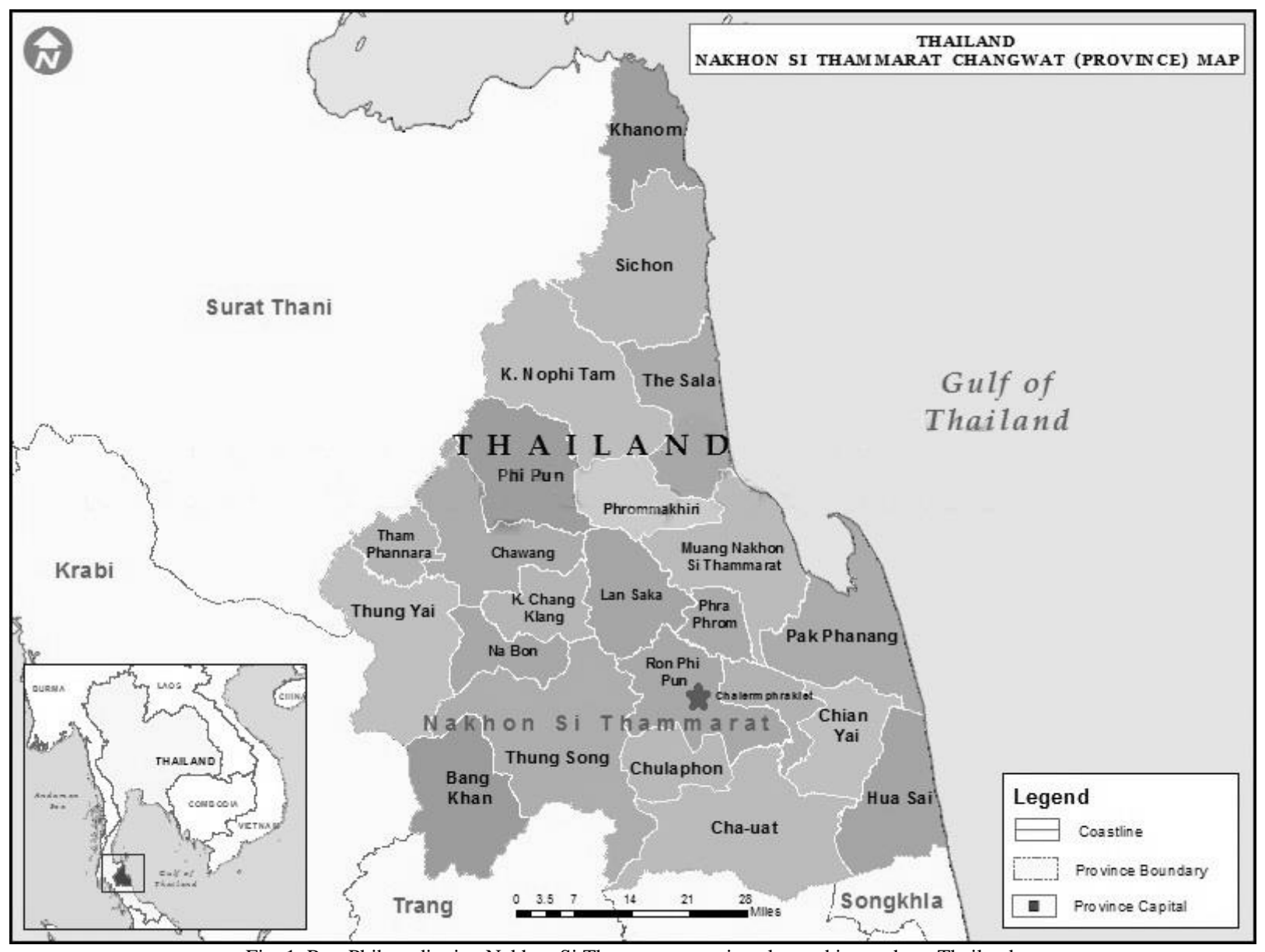

Fig. 1. Ron Phibun district, Nakhon Si Thammarat province located in southern Thailand.

\section{B. Sample Preparation and Analysis}

A total of five rice samples were collected and gently washed with Milli-Q water to remove the dust particles. Then the samples were dried in a hot air over to obtain the constant weight and digested with nitric acid in the Teflon microwave vessel under high pressure and temperature conditions with microwave-assisted technique according to EPA Method 3051. Rice digested solutions were filtered and analyzed for arsenic using inductively coupled plasma optical emission spectrometry (ICP-OES) according to EPA Method 6010. Precision and accuracy of analysis were ensured by blank and quality control standard in duplicate. The certified standard and a blank solution were run. Deionized water was used throughout the laboratory test. All reagents were of analytical grade. Recoveries obtained with the proposed method were over $95 \%$.

\section{Estimated Daily Intake (EDI)}

The estimated daily intake, common index for metal transfer from plant to human, to obtain the estimation of dietary exposure is calculated as follows [23]:

$$
E D I=\frac{C \times C o n s}{B w}
$$

where $\mathrm{C}$ stand for the concentration of arsenic in rice; Cons represents daily average consumption of rice; and $\mathrm{Bw}$ is the body weight. The risk characterization is based on an average adult weighting $60 \mathrm{~kg}$.

\section{RESULTS AND DiSCUSSIONS}

\section{A. Concentrations of Arsenic in Rice Samples}

Rice samples collected from three sub districts exhibits arsenic concentrations in the range of $0.291-1.361 \mathrm{mg} / \mathrm{kg}$ as shown in Table II. The highest concentration of arsenic was found in Khun Chum sub district at $1.361 \mu \mathrm{g} / \mathrm{kg}$ and while others ranged from 0.291 to $0.619 \mu \mathrm{g} / \mathrm{kg}$. All samples were not exceeded the maximum permitted level recommended in Thai FDA and WHO standard ( $2 \mathrm{mg} / \mathrm{kg})$.

\section{B. Estimated Daily Intake of Arsenic}

A study of risk assessment of arsenic were carried out. The local people was assumed to consume the local rice. In Thailand, rice consumption per capita is $114.57 \mathrm{~kg} / \mathrm{yr}$ [24]. The body weight was set to $60 \mathrm{~kg}$. The provisional tolerable weekly intake (PTWI) of $15 \mu \mathrm{g} / \mathrm{kg}$ bw/week (equivalent to $2.1 \mu \mathrm{g} / \mathrm{kg}$ bw/day) for inorganic arsenic was recommended by the Joint FAO/WHO Expert Committee on Food Additives (JECFA) [25]. The estimated daily intake of arsenic through rice consumption, shown in Table II, were ranged from 1.522 to $7.120 \mu \mathrm{g} /$ day $\mathrm{kg}$ body weight which are 
lower than a Maximum Allowable Daily Body Load (MADL) of total arsenic of $50 \mu \mathrm{g} / \mathrm{kg}$ bw/day set in 1967 by the Thai FDA and WHO.

TABLE I: RICE SAMPLING SITES

\begin{tabular}{llll}
\hline \hline Sample & $\begin{array}{l}\text { Location } \\
\text { (Sub district) }\end{array}$ & Latitude & Longitude \\
\hline R1 & Khuan Chum & 8.18827 & 99.90088 \\
R2 & Khuan Koei & 8.10953 & 99.90281 \\
R3 & Khuan Koei & 8.11040 & 99.90137 \\
R4 & Khuan Phang & 8.15155 & 99.94498 \\
R5 & Khuan Phang & 8.15378 & 99.94457 \\
\hline \hline
\end{tabular}

TABLE II: CONCENTRATIONS OF ARSENIC IN RICE SAMPLES AND EDI

\begin{tabular}{llll}
\hline \hline Sample & $\begin{array}{l}\text { Location } \\
(\text { Sub district) }\end{array}$ & $\begin{array}{l}\text { Concentration of } \\
\text { arsenic }(\mu \mathrm{g} / \mathrm{kg})\end{array}$ & $\begin{array}{l}\text { EDI } \\
(\mu \mathrm{g} / \mathrm{day} \mathrm{kg} \mathrm{bw})\end{array}$ \\
\hline R1 & Khuan Chum & 1.361 & 7.120 \\
R2 & Khuan Koei & 0.619 & 3.238 \\
R3 & Khuan Koei & 0.538 & 2.815 \\
R4 & Khuan Phang & 0.600 & 3.139 \\
R5 & Khuan Phang & 0.291 & 1.522 \\
\hline \hline
\end{tabular}

The results of study showed the lower concentration of arsenic in rice samples than the Thai FDA and WHO criteria. Moreover, arsenic estimated daily intake exposed by rice consumption also showed that the arsenic daily intake in Ron Phibun district is lower than the MADL.

\section{CONCLUSIONS}

Since Ron Phibun district has a long history of tin mining, therefore the large amounts of arsenic released into the environment were historically reported. Rice cultivation areas in Ron Phibun district have been transformed to other economic crop farming, i.e., rubber tree and palm, and the industrial zone, therefore, rice production are mainly for household consumption. Thus the ingestion of self-planted rice was considered to be the main exposure route of arsenic which causes the health risk for local people. Moreover, the contamination of arsenic in rice and the level of arsenic exposure to environment and the nearby agricultural area should be monitored and concerned. Long-term heavy metal through the regular consumption of rice and vegetables and the ingestion of heavy metal from water and soil in the vicinity of mining site should be further investigated. Greater attention for protective measure to avoid the potential health risk through the consumption of local crops and the ingestion of contaminated soil and water around the former mining site should also be considered, regulated and advised to the local population.

\section{ACKNOWLEDGMENT}

This work was supported and funded by Graduate School, Prince of Songkla University, Faculty of Environmental Management, Prince of Songkla University, Thailand and Department of Marine Environmental Engineering, National Kaosiung Marine University, Taiwan.

\section{REFERENCES}

[1] H. Jones, P. Visoottiviseth, K. Bux, R. FÖldényi, N. Kováts, G. Borbély, and Z. Galbács, "Case reports: Arsenic pollution in Thailand,
Bangladesh, and Hungary,” Rev Environ Contam Toxicol, vol. 197, pp. 163-187, 2008.

[2] H. Cao, J. Chen, J. Zhang, H. Zhang, L. Qiao, and Y. Men, "Heavy metals in rice and garden vegetables and their potential health risks to inhabitants in the vicinity of an industrial zone in Jiangsu, China," $J$ Environ Sci, vol. 22, pp. 1792-1799, 2010.

[3] J. Lee, H. Chon, and K. Kim, "Human risk assessment of As, $\mathrm{Cd}, \mathrm{Cu}$ and $\mathrm{Zn}$ in the abandoned metal mine site," Environ Geochem Health, vol. 27, pp. 185-191, 2005.

[4] H. Y., Liu, A. Probst, and B. H. Liao, "Metal contamination of soils and crops affected by the Chenzhou lead zince mine spill (Hunan, China), Sci Total Environ, vol. 339, pp. 153-166, 2005.

[5] X. S. Hang, H. Y. Wang, J. M. Zhou, c. L. Ma, C. W. Du, and X. Q. Chen, "Risk assessment of potentially toxic element pollution in soils and rice (Oryza sativa) in a typical area of the Yangtze River delta," Environ Pollut, vol. 157, pp. 2542-2549.

[6] N. Zheng, Q. C. Wang, and D. M. Zheng, "Health risk of $\mathrm{Hg}, \mathrm{Pb}, \mathrm{Cd}$, $\mathrm{Zn}$, and cu to the inhabitants around Huludao Zinc Plant in China via consumption of vegetables," Sci Total Environ, vol. 383, pp. 81-89, 2007.

[7] F. Zeng, W. Wei, M. Li, R. Huang, F. Yang, and Y. Duan, "Heavy metal contamination in rice-producing soils of Hunan province, China and potential health risks," Int J Environ Res Public Health, vol. 12, pp. 15584-15593. 2015.

[8] H. T. Lin, S. S Wong, and G. C. Li, "Heavy metal content of rice and shellfish in Taiwan," J Food Drug Anal, vol. 12, pp. 167-174, 2004.

[9] M. A. Zazouli, M. Shokrzadeh, H. Izanloo, and S. Fathi, "Cadmium content in rice and its daily intake in Ghaemshahr region of Iran," Afr J Biotechnol, vol. 7, pp. 3686-3689, 2008.

[10] G. R. Khaniki and M. A. Zozali, "Cadmium and lead contents in rice (oryza sativa) in the north of Iran," Int J Agric Biol, vol. 6, pp. 1026-1029, 2005.

[11] P. Visoottiviseth, K. Francesconi, and W. Sridokchan, "The potential of Thai indigenous plant species for the phytoremediation of arsenic contaminated land," Enrivon Pollut, vol. 118, pp. 453-461, 2002.

[12] M. Williams, F. Fordyce, A. Paijitprapanon, and P. Charoenchaisri, "Arsenic contamination in surface drainage and groundwater in part of the Southeast Asian Tin belt, Nakhon Si Thammarat province, southern Thailand," Environ. Geol, vol. 27, pp. 16-33, 1996.

[13] WHO, Guideline for Drinking-Water Quality, $4^{\text {th }}$ ed., 2011.

[14] U.S. FDA. Analytical results from inorganic arsenic in rice and rice $\begin{array}{lll}\text { products sampling. } & \text { [Online]. Available: }\end{array}$ http://www.fda.gov/food/foodborn-illnesscontaminants/metals/ucm31 9870.htm

[15] K. M. Saha, A. K. Dikshit, and M. A. Bandyopadhyay, "A review of arsenic poisoning and its effect on human health," CritRev Environ Sci Technol, vol. 29, pp. 281-313, 1999.

[16] F. J. Zhao, S. P. McGrath, and A. A. Meharg, "Arsenic as a food chain contaminant: mechanisms of plant uptake and metabolism and mitigation strategies," Апnи Rev Plant Biolo, vol. 61, pp. 535-559, 2010.

[17] D. Halder, A. Biswas, Z. Šlejkovec, D. Chatterjee, J. Nriagu, G. Jacks, and P. Bhattacharya, "Arsenic species in raw and cooked rice: Implications for human health in rural Bengal," Sci Total Environ, vol. 497-498, pp. 200-208, 2014.

[18] A. A. Meharg and M. M. Rahman, "Arsenic contamination of Bangladesh paddy field soils: implications for rice contribution to arsenic consumption," Environ Sci Technol, vol. 37, pp. 229-34, 2003.

[19] P. N. Williams, A. Villada, C. Deacon, A. Raab, J. Figrrola, A. J. Green, J. Feldmann, and A. A. Meharg, "Greatly enhanced arsenic shoot assimilation in rice leads to elevated grain levels compared to wheat and barley," Environ Sci Technol, vol. 41, pp. 6854-6859., 2007.

[20] D. Mondal and D. A. Polya, "Rice is a major exposure rote for arsenic in Chakdaha block, Nadia district, West Bengal, India: a probabilistic risk assessment," Appl Geochem, vol. 23, pp. 2987-2998, 2008.

[21] R. M. Tripathi, R. Raghunath, and T. M. Krishnamoorthy, "Dietary intake of heavy metals in Bombay city, India," Sci Total Environ, vol. 208, pp. 149-159, 1997.

[22] P. Zhuang, B. B. McBride, H. P. Xia, N. Y. Li, and Z. A. Li, "Health risk from heavy metals via consumption of food crops in the vicinity of Dabaoshan mine, South China," Sci Total Environ, vol. 407, pp. 1551-1561, 2009

[23] A. Chamannejadian, G. Sayyad, A. Moezzi, and A. Jahangiri, "Evaluation of estimated daily intake (EDI) of cadmium and lead for rice (Oryza sativa L.) in calcareous soils," Iranian J Environ Health Sci Eng, vol. 10, 2013.

[24] IRRI. World rice statistics online query facility. [Online]. Available: http://ricestat.irri.org:8080/wrs 
[25] WHO, "Toxicological evaluation of certain food additives and contaminants," Geneva, 1989.

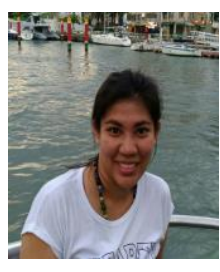

Pornpun Phimol was born in Nakhon Si Thammarat, Thailand in 1979. She is currently the Ph.D. candidate at Faculty of Environmental Management. She got the master of science in analytical chemistry from Prince of Songkla University, Thailand in 2007.

She has been working as the coordinator at Agri-Nature Foundation since 2007 and worked as the lecturer at Rajamangala University of Technology during 2001-2003. Her research interests are risk assessment, pollution, environment, organic farming, food security and sustainability.

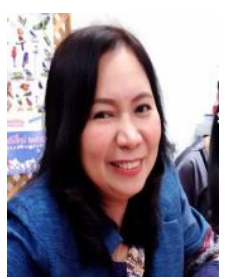

Parichart Visuthismajarn was born in Thailand. She got the Dr. Phil. in biogeography from University of Saarland Federal, Germany in 1998 and the master of environmental risk assessment for tropical from Chiangmai University, Thailand in 1994.

She currently serves as lecturer at Faculty of Environmental Manage, Prince of Songkla University since and the Director of Research Center of Ecotourism Integrated Management in Southern Thailand. Her research interests are risk assessment, environmental management, food security, sustainability and ecotourism.



Chitsan Lin was born in Taiwan. He got the Ph.D. in environmental engineering, University of Connecticut in 1995 and the master of environmental engineering from New Jersey Institute of Technology in 1988.

$\mathrm{He}$ is currently serves as a professor of the Department of Marine Environmental Engineering and was the Dean of the College of Ocean Engineering of National Kaohsiung Marine University, Taiwan during 2009-2012. Prof.Chitsan Lin was invited to join the editorial board member of the Environmental Engineering Science and US based journal published by the Mary Anne Liebert Publisher in the United States. His research interests are environmental monitoring sampling and analysis, soil and groundwater remediation, pollution prevention, recycling and food wastes composting.

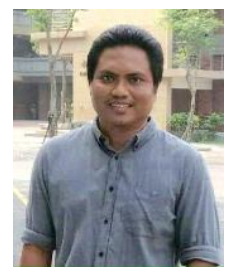

Sanae Rukkur was born in Thailand in 1976. He got the Ph.D. in mechanical engineering 2014 and the master of mechanical engineering in 2007 from Prince of Songkla University, Thailand.

$\mathrm{He}$ is currently serves as a lecturer of Rajamangala University of Technology Srivijaya. His research interests are sustainable development, sustainable agriculture, natural materials, recycling and food wastes composting, agricultural machinery, alternative energy and applied mechanics. 